\title{
Estimating Carbon Reductions of Green Highway Technologies
}

\author{
Jongdae Baek, Hyejung Hu, Guenhee Lee, and Geonho Kim
}

\begin{abstract}
There are great activities around developing and applying new green highway technologies to reduce carbon emissions around the world. This study introduces three green highway technologies related to road construction materials and method that are among many other technologies developed by the Carbon Neutral Road Technologies Research Group in Korea. They are (technology A) manufacture and construction of carbon-absorbing road facilities utilizing activated industrial by-products, (technology B) low carbon non-cement soil pavement utilizing industrial by-products and inorganic binder, (technology C) low carbon soil pavement utilizing polymer concrete. Comparative carbon reduction by the three technologies calculated via G-TIES (Green Highway Technology Investment Evaluation System) developed by the research group to evaluate investment benefits of green highway technologies is also included in the study. When technology A are applied to construction and operation of curbs in $1 \mathrm{~km}$ road section, it can reduce $2.69 \mathrm{tCO}_{2}$ in the construction stage and $24.75 \mathrm{tCO}_{2}$ in the operation stage to reach $27.44 \mathrm{tCO}_{2}$ in total carbon emissions compared to the existing technology when assuming road operation for 30 years. When technology $B$ and $C$ are applied to $1 \mathrm{~km}$ road pavement construction, $598 \mathrm{tCO}_{2}$ and $404.97 \mathrm{tCO}_{2}$, respectively, will be reduced. Green technologies outlined in this paper, actual reduction of carbon emissions and methodologies used to calculate reduction will hopefully serve as a good reference to researchers and technology developers.
\end{abstract}

Index Terms - Carbon emissions, low carbon, green highway technology, evaluation system.

\section{INTRODUCTION}

Global warming caused by greenhouse gas (GHG) and the resulting climate change have become an issue confronting the very survival of mankind. Fortunately, there have been great global initiatives to address such issues. That carbon dioxide is the biggest cause among other greenhouse gases of greenhouse effect is a fact widely known. This is why reduction of carbon emissions is the focus of policies, programs and technological developments aimed at making industries more eco-friendly. Many countries are working hard to reduce a vast amount of carbon emitted during road

Manuscript received September 15, 2014; revised January 6, 2015. This paper is based on the work done under the Carbon Neutral Road Technologies Development project of the 2011 Construction Technology Innovation Program. The authors thank the Korea Agency for Infrastructure Technology Advancement (KAIA) and the Ministry of Land, Infrastructure and Transport (MOLIT) for the research support.

Jongdae Baek, Hyejung $\mathrm{Hu}$, and Guenhee Lee are with the Highway and Transportation Division, Korea Institute of Civil Engineering and Building Technology Technology, 283 Goyangdae-Ro, Gyeonggi 411-712, Republic of Korea (e-mail: jdbaek@kict.re.kr, hhu@kict.re.kr, ghlee@kict.re.kr).

Geonho Kim is with YESSorg Co., Ltd., 148-11, Gwangjang-dong, Gwangjin-gu, Seoul, 143-802, Republic of Korea (e-mail: kykim@yess.or.kr). construction and operation. Related efforts include studies on new materials and construction techniques, development of methodologies to calculate how much new materials and construction techniques reduce carbon emissions during construction and operation, development of calculation tools and green road certification system to encourage and promote application of such eco-friendly green technologies.

Many GHGs related decision making support tools were already developed. REAP [1] was created for evaluating potential environmental impacts of road policies and monitoring the actual impact over time. HDM-4 [2] was designed for road management, programming road works, estimating funding requirements, budget allocations, predicting road network performance, project appraisal, and policy impact studies. INVEST [3] enables transportation agencies to evaluate the sustainability of their road projects. CHANGER [4], Highways Agency Carbon Tool [5], Carbon Gauge Tool [6], and ROADEO [7] were developed for calculating greenhouse gas emissions from road works such as construction, operation, and maintenance.

According to CDIAC (Carbon Dioxide Information Analysis Center), Korea is the $8^{\text {th }}$ largest emitter of $\mathrm{CO}_{2}$ in the world as of 2010 [8]. The Korean government, hence, has set 'Low Carbon, Green Growth' as the key slogan and has been making various initiatives to tackle the issue. In 2009, $15 \%$ of nationwide GHG emissions were represented by the road sector [9]. In 2011, the government launched a research group to carry out a project on Carbon Neutral Road Technologies Development in order to aid the road sector's contribution to sustainable green growth of the country. Objective of the project is to develop a wide breadth of green highway technologies to reduce carbon emissions in roads. 'Carbon Neutral Road' in this study refers to 'a road in which the carbon emissions is 'zero' by minimizing the emissions and capturing, converting, and disposing the emitted carbon in all road life-cycle'. Green Highway means a road ensuring a safe and comfortable mobility while minimizing the emissions of GHGs and pollutants by saving and efficiently using the energy and resources. Green Highway is the ultimate road from the view point of sustainability, which includes all 'green' oriented functions such as Green Network, energy harvesting, etc. [10].

The research group not only studies development of various road construction materials and technologies conducive to reducing carbon emissions but also development of G-TIES (Green Highway Technology Investment Evaluation System), which is a tool to calculate carbon emitted when green highway technologies are in place and to evaluate subsequent reduction in carbon emissions. In this study, three out of numerous green highway technologies 
under development by the research group are introduced i.e. (1) manufacture and construction of carbon-absorbing road facilities utilizing activated industrial by-products, (2) low carbon non-cement soil pavement utilizing industrial by-products and inorganic binder, (3) low carbon soil pavement utilizing polymer concrete. The study also outlines methodologies used to calculate reduction in carbon emissions when the three technologies are applied by utilizing G-TIES and actual reductions. These study findings are expected to (1) give new options for road designers and construction companies in designing and constructing new roads, (2) offer benchmarking opportunities to researchers of carbon-reducing green highway technologies and (3) provide carbon emission calculation samples to carbon emission calculation tool owners or developers.

\section{GREEN HighWAY TECHNOLOGIES}

\section{A. Manufacture and Construction of Carbon-Absorbing} Road Facilities Utilizing Activated Industrial By-products

The purpose of technology $\mathrm{A}$ is to develop road and structure materials whose $\mathrm{CO}_{2}$ capture and sequestration efficacy is above $50 \mathrm{~g}-\mathrm{CO}_{2} / \mathrm{kg}$ by utilizing activated industrial by-products. Use of blast furnace slag, which is an industrial by-product, over cement when manufacturing concrete for roads and other structure not only reduces cement consumption and subsequent reduction in $\mathrm{CO}_{2}$ emissions but also enables capture of $\mathrm{CO}_{2}$ by activating blast furnace slag and modifying the surface of roads and other structures. Fig. 1 is concept of technology A.
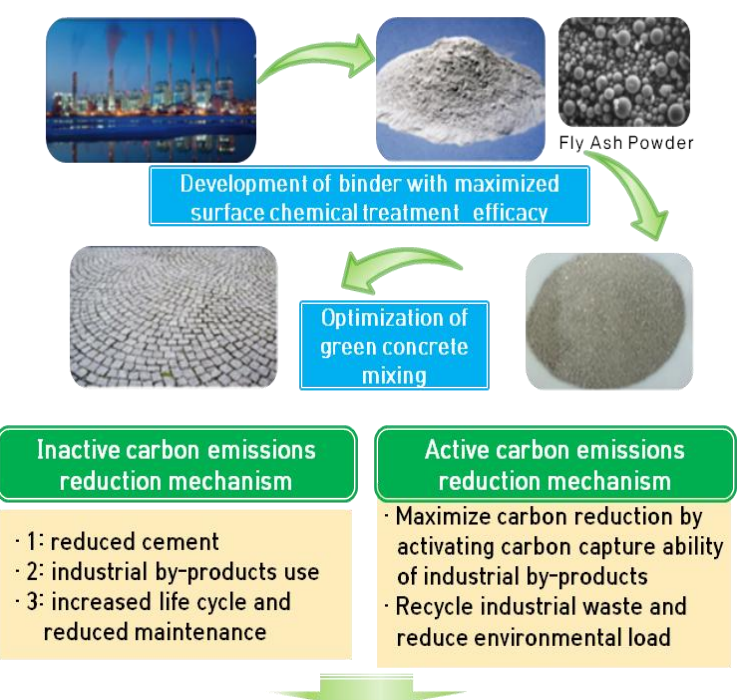

Developing and implementing of carbonabsorbing road facility materials utilizing activated industrial by-products

Fig. 1. Concept of developing carbon-absorbing road facilities materials utilizing activated industrial by-products.

\section{B. Low Carbon Non-cement Soil Pavement Utilizing Industrial By-products and Inorganic Binder}

The purpose of this technology is to develop inorganic binder, which substitutes cement, by utilizing industrial by-products like blast furnace slag and fly ash and to take advantage of non-cement inorganic binder to develop eco-friendly soil pavement materials and construction technologies. In the existing soil pavement, cement is absolutely needed since it is mixed with hardener. But this technology replaces cement with mixture of industrial by-products, which not only boosts recycling of industrial by-products, but also reduces cement use and the amount of carbon emitted as a result.

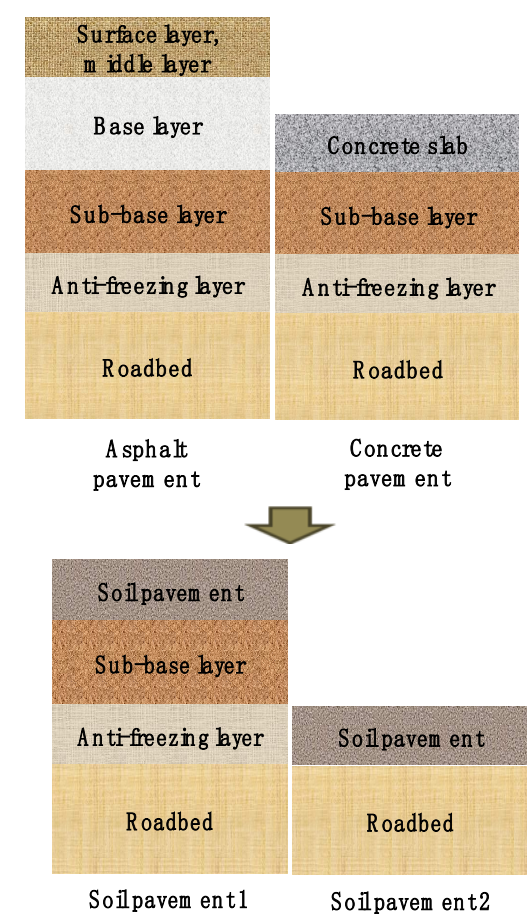

Fig. 2. Comparison of asphalt/cement concrete and low carbon soil pavement.

\section{Low Carbon Soil Pavement Utilizing Polymer Concrete}

The purpose of this technology is to develop low carbon soil pavement materials and construction technologies by utilizing organic binder. Low carbon soil pavement is eco-friendly and its construction is quick and simple. It also reduces carbon emissions by replacing asphalt or cement. Fig. 2 compares the existing asphalt/cement concrete pavement structure and low carbon soil pavement structure. This soil pavement technology can replace the existing asphalt or cement concrete in the pavement layer, under layer and even sub-base layer.

\section{Calculation Methodologies of CARbon Emissions REDUCTION BASED ON GREEN HIGHWAY TECHNOLOGY APPLICATION}

This section introduces methodologies used to calculate carbon emissions reduction by applying green highway technology as performed by G-TIES development team as part of the research project on Carbon Neutral Road Technologies Development

\section{A. Calculation Method}

Fig. 3 is the method and flow of calculating reduction in carbon emissions against the existing technology when green highway technology is applied to road construction or maintenance. First, team dedicated to developing individual green highway technology provides all required information 
and data on green highway technology such as road life cycle (construction, maintenance, and operation stage), specific work of construction applied to the particular life cycle, the amount of materials and equipment used for the technology in

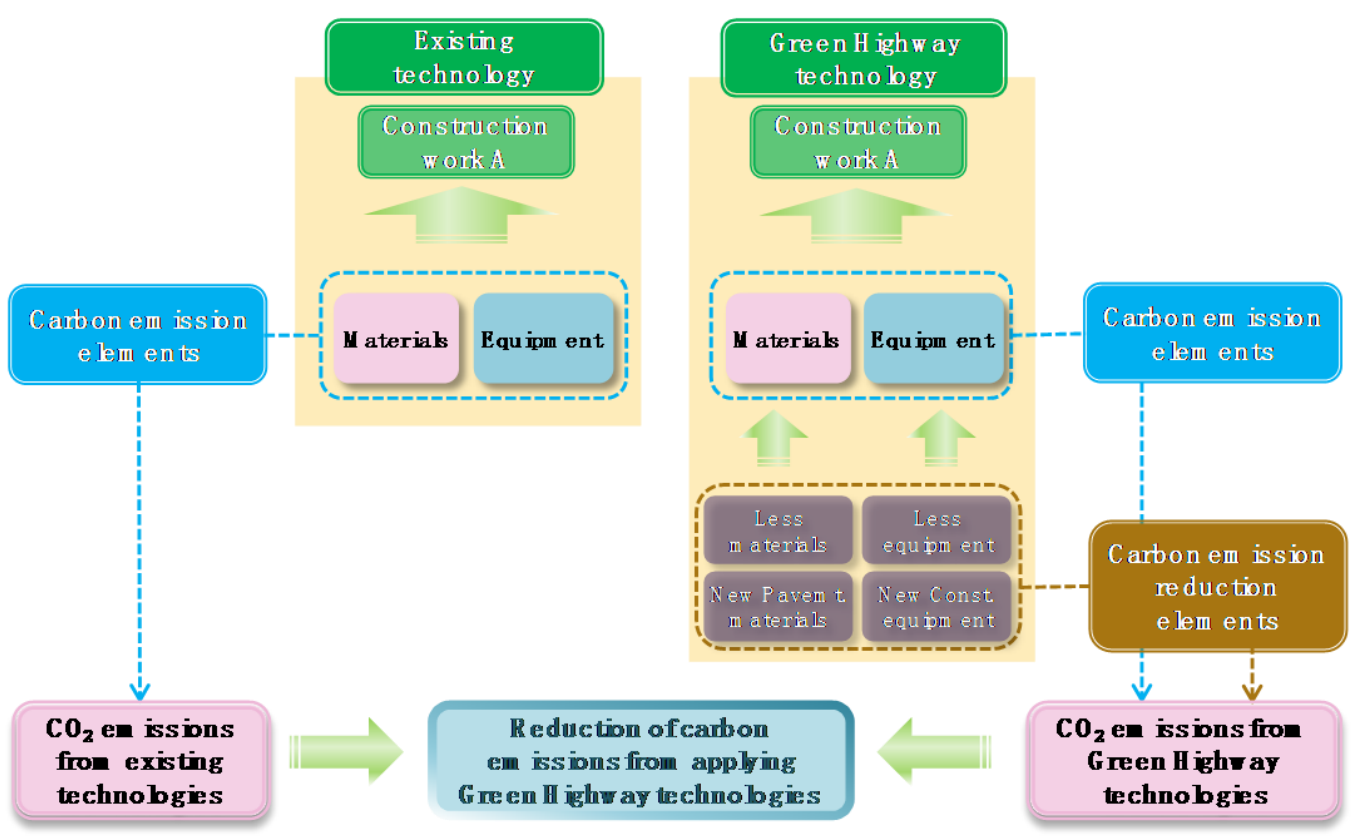

Fig. 3. Calculation of carbon reduction by applying green highway technologies.

Total carbon emissions in the existing construction technology are calculated from the volume of carbon emissions elements like construction materials and equipments used. For green highway technology, in addition to the volume of materials and equipment used, the volume of carbon-reducing elements is also calculated when necessary to calculate total carbon emissions. The difference between the two becomes reduction of carbon emissions gained when a green highway technology is applied to construct a $1 \mathrm{~km}-$ long road section.

\section{B. Average Carbon Emissions by Construction Material and Construction Work Applied}

The study accessed LCI (Life Cycle Inventory) database [11] the Korean government operates in order to calculate reduction of carbon emitted from construction materials assuming application of green highway technologies. The database includes information on standard carbon emissions coefficient of cement and other various construction materials.

Average carbon emissions per construction work set by the research project on Carbon Neutral Road Technologies Development was used for specific work of road construction and maintenance in order to calculate reduction of carbon emissions in technology C. Actual consumption of energy from materials and equipment used for each specific construction work was calculated based on design configuration and other construction data of other roads already constructed. It was then multiplied with each carbon emission coefficient to determine total carbon emissions per construction work, which is then divided by the length of each construction case to obtain the average carbon emissions per unit length of road. Table I shows sample construction case to calculate average carbon emissions per construction work. order to calculate reduction in carbon emissions. All these data are used to calculate total amount of materials and equipment consumed for building a $1 \mathrm{~km}$ long four-lane road (20 $\mathrm{m}$ wide) section.

TABLE I: SAMPLE CONSTRUCTION CASES USED FOR CALCULATING AVERAGE CARBON EMISSIONS PER CONSTRUCTION WORK OF CEMENT CONCRETE PAVEMENT

\begin{tabular}{|c|c|}
\hline CONSTRUCTION WORK & APPLIED SAMPLE CONSTRUCTION CASE \\
\hline $\begin{array}{l}\text { Soil transportation - Dozer } \\
\text { transportation }\end{array}$ & $\begin{array}{c}2^{\text {nd }} \text { construction section of Busan Outer } \\
\text { Ring Expressway }\end{array}$ \\
\hline $\begin{array}{l}\text { Soil transportation }- \text { dump } \\
\text { transportation }\end{array}$ & $\begin{array}{c}2^{\text {nd }} \text { construction section of Busan Outer } \\
\text { Ring Expressway }\end{array}$ \\
\hline $\begin{array}{l}\text { Anti-freezing layer laying and } \\
\text { compacting }\end{array}$ & $\begin{array}{c}12^{\text {th }} \text { construction section of } 88 \text { National } \\
\text { Expressway }\end{array}$ \\
\hline $\begin{array}{l}\text { Sub-base layer laying and } \\
\text { compacting }\end{array}$ & $\begin{array}{l}12^{\text {th }} \text { construction section of } 88 \text { National } \\
\text { Expressway }\end{array}$ \\
\hline $\begin{array}{c}\text { Concrete pavement work - } \\
\text { concrete layer - cement } \\
\text { stabilization filter layer }\end{array}$ & $\begin{array}{c}2^{\text {nd }} \text { construction section of Busan Outer } \\
\text { Ring Expressway }\end{array}$ \\
\hline $\begin{array}{l}\text { Concrete pavement work - } \\
\text { concrete laying and curing }\end{array}$ & $\begin{array}{c}\text { 1-1 construction section of } \\
\text { Sangju-Yeongdeok National Expressway }\end{array}$ \\
\hline
\end{tabular}

\section{RESULTS}

\section{A. Manufacture and Construction of Carbon-Absorbing Road Facilities Utilizing Activated Industrial By-products}

Analysis of the effect of technology A on carbon emissions reduction assumed cement curb construction on a $1 \mathrm{~km}$-long road. Table II represents change in the amount of materials used and reduction in carbon emissions when the three technologies are applied to a four-lane ( $20 \mathrm{~m}$ wide) road $1 \mathrm{~km}$ in length. Usually, 4 tons $(4,032 \mathrm{~kg}$ ) of cement is used to build curb in a $1 \mathrm{~km}$-long road but cement can be saved by around 3 tones $(2,822 \mathrm{~kg})$ when applying technology $\mathrm{A}$ and blast furnace slag is used as a substitute of cement.

The study applied the carbon emissions coefficient related to cement manufacture in Korea's LCI database in order to calculate carbon reduction during the construction stage. In this study, carbon emissions coefficient of "Work 1 Portland cement" is applied, which is $0.000952 \mathrm{tCO}_{2} / \mathrm{kg}$. Carbon 
emissions from the existing technology and green highway technology gained by multiplying cement consumed with carbon emissions coefficient are $3.84 \mathrm{tCO}_{2} / \mathrm{km}$ and 1.15 $\mathrm{tCO}_{2} / \mathrm{km}$, respectively. As blast furnace slag is an industrial by-product of iron manufacturing process, carbon emissions from using it is almost zero since it is recycled. Hence, carbon emissions are reduced by $2.69 \mathrm{tCO}_{2} / \mathrm{km}$ when this technology is applied to $1 \mathrm{~km}$-long road.

TABLE II: CHANGE In AMOUNT OF MATERIALS/CONSTRUCTION WORK USED AND CARBON REDUCTION FROM APPLYING GREEN HighWAY TECHNOLOGIES A,

\begin{tabular}{|c|c|c|c|c|c|c|c|c|c|}
\hline \multirow[t]{2}{*}{$\begin{array}{c}\text { Green } \\
\text { technology }\end{array}$} & \multirow[t]{2}{*}{$\begin{array}{l}\text { Construction } \\
\text { materials/work }\end{array}$} & \multicolumn{3}{|c|}{$\begin{array}{l}\text { Materials/construction work } \\
\text { consumed(unit/km) }\end{array}$} & \multirow{2}{*}{$\begin{array}{l}\text { Reduction in } \\
\text { amount of } \\
\text { materials/ } \\
\text { construction } \\
\text { work }\end{array}$} & \multirow{2}{*}{$\begin{array}{c}\text { Carbon } \\
\text { emissions } \\
\text { coefficient } \\
\text { (tCO } \mathrm{tCO}_{2} \text { /unt) }\end{array}$} & \multirow{2}{*}{$\begin{array}{l}\text { Reduction of } \\
\text { emissions } \\
\left(\mathrm{tCO}_{2} / \mathrm{km}\right)\end{array}$} & \multirow{2}{*}{$\begin{array}{c}\text { Average } \\
\text { absorption } \\
\left(\mathrm{tCO}_{2} / \mathrm{km} / \mathrm{yr}\right)\end{array}$} & \multirow{2}{*}{$\begin{array}{c}\text { Absorption amount } \\
(30 \mathrm{yr}) \\
\left(\mathrm{tCO}_{2} / \mathrm{km} / 30 \mathrm{yr}\right)\end{array}$} \\
\hline & & $\begin{array}{l}\text { Existing } \\
\text { technology }\end{array}$ & $\begin{array}{c}\text { Green } \\
\text { technology }\end{array}$ & unit & & & & & \\
\hline \multirow{3}{*}{$\begin{array}{l}\text { Technology } \\
A^{*}\end{array}$} & Cement & 4,032 & 1,210 & $\mathrm{~kg}$ & 2,822 & 0.000952 & 2.69 & - & - \\
\hline & Blast furnace slag & 0 & 2,822 & $\mathrm{~kg}$ & $-2,822$ & 0 & 0 & 0.825 & 24.75 \\
\hline & Total & & & & & & 2.69 & - & 24.75 \\
\hline \multirow[t]{8}{*}{$\begin{array}{l}\text { Technology } \\
\text { B** }\end{array}$} & $\begin{array}{l}\text { Weathered granite } \\
\text { soil }\end{array}$ & 5,600 & 5,600 & Ton & 0 & - & 0 & - & - \\
\hline & Cement & 1,200 & 0 & Ton & 1,200 & 0.952 & $1,141.94$ & - & - \\
\hline & Water & 1,200 & 200 & $\mathrm{kl}$ & 1,000 & 0.000102 & 0.10 & - & - \\
\hline & Sodium silicate & 0 & 320 & Ton & -320 & 1.542941 & -493.74 & - & - \\
\hline & $\mathrm{NaOH}$ & 0 & 80 & Ton & -80 & 0.631126 & -50.49 & - & - \\
\hline & Fly ash & 0 & 500 & Ton & -500 & 0 & 0 & - & - \\
\hline & Blast furnace slag & 0 & 500 & Ton & -500 & 0 & 0 & - & - \\
\hline & Total & & & & & & $\mathbf{5 9 7 . 8 1}$ & - & - \\
\hline \multirow[t]{8}{*}{$\begin{array}{l}\text { Technology } \\
\text { C } * * *^{*}\end{array}$} & Polyurethane & - & 457,143 & $\mathrm{~kg}$ & $-457,143$ & 0.002407 & $-1,100.17$ & - & - \\
\hline & $\begin{array}{l}\text { Soil transportation } \\
\text {-Dozer }\end{array}$ & 1 & 1 & $\mathrm{~km}$ & 0 & 7.13 & 0 & - & - \\
\hline & $\begin{array}{l}\text { Soil transportation - } \\
\text { dump }\end{array}$ & 1 & 1 & $\mathrm{~km}$ & 0 & 238.29 & 0 & - & - \\
\hline & $\begin{array}{l}\text { Anti-freezing layer } \\
\text { laying and } \\
\text { compacting }\end{array}$ & 1 & 0 & $\mathrm{~km}$ & 1 & 5.65 & 5.65 & - & - \\
\hline & $\begin{array}{l}\text { Sub-base layer laying } \\
\text { and compacting }\end{array}$ & 1 & 0 & $\mathrm{~km}$ & 1 & 9.48 & 9.48 & - & - \\
\hline & $\begin{array}{l}\text { Concrete } \\
\text { layer-cement } \\
\text { stabilization filter } \\
\text { layer }\end{array}$ & 1 & 0 & $\mathrm{~km}$ & 1 & 2.56 & 2.56 & - & - \\
\hline & $\begin{array}{l}\text { Concrete laying and } \\
\text { curing }\end{array}$ & 1 & 0 & $\mathrm{~km}$ & 1 & $1,487.45$ & $1,487.45$ & & \\
\hline & Total & & & & & & 404.97 & - & - \\
\hline
\end{tabular}

*Technology A: manufacture and construction of carbon-absorbing road facilities utilizing activated industrial by-products

** Technology B: low carbon non-cement soil pavement utilizing industrial by-products and inorganic binder

*** Technology C: low carbon soil pavement utilizing polymer concrete

Carbon absorption is also calculated to identify the carbon-absorption function, which is one of the most notable advantages of this technology, based on the assumption that the road keeps in operation for 30 years. Road curb applied with technology A can absorb $0.825 \mathrm{tCO}_{2}$ of carbon a year on $1 \mathrm{~km}$-long road, which translates into $24.75 \mathrm{tCO}_{2}$ in total carbon absorption for the 30 years. In short, 30 -year operation of $1 \mathrm{~km}$-long road built with technology A will be able to reduce carbon by $27.44 \mathrm{CO}_{2} / \mathrm{km}: 2.69 \mathrm{tCO}_{2} / \mathrm{km}$ in the construction stage and $24.75 \mathrm{tCO}_{2} / \mathrm{km}$ in the operation stage compared to the existing technology.

\section{B. Low Carbon Non-cement Soil Pavement Utilizing Industrial By-products and Inorganic Binder}

Table II suggests carbon reduction when technology B is applied to a four-lane (20 m wide) road $1 \mathrm{~km}$ in length. As shown in Table II, the amount of soil used is the same in both technology B and the existing soil pavement technology but amount of cement and water can be saved by 1,200 ton and $1,000 \mathrm{~kL}$ in the former. Instead, fly ash and blast furnace slag, which are industrial by-product, sodium silicate and sodium hydroxide are consumed in amount as suggested in Table II.

Carbon emissions coefficient in Korea's LCI database is applied to calculating reduction of carbon emissions (Table II). The amount of materials saved is multiplied by the carbon emissions coefficient to determine carbon emissions reduced as a result of the green technology applied. Total reduction from consuming less cement and water compared to the existing technology on a $1 \mathrm{~km}$ long four-lane road section is approximately $1,142 \mathrm{tCO}_{2} / \mathrm{km}$. Carbon emissions as a result of consuming sodium silicate and sodium hydroxide are 494 $\mathrm{tCO}_{2} / \mathrm{km}$ and $50 \mathrm{tCO}_{2} / \mathrm{km}$, respectively. In short, total 
reduction of carbon emissions from applying technology $\mathrm{B}$ is around $598 \mathrm{tCO}_{2} / \mathrm{km}$. There is no carbon absorbed since soil pavement from applying technology B cannot absorb carbon.

\section{Low Carbon Soil Pavement Utilizing Polymer Concrete}

Replacement of the existing cement concrete slab, sub-base layer and anti-freezing layer with soil pavement on a $1 \mathrm{~km}$ long four-lane road section was assumed to calculate reduction of carbon emissions from applying technology $\mathrm{C}$. Amount of materials and construction work used, carbon emissions coefficient, and reduction in carbon emissions are indicated in Table II. 457 tons of polyurethane polymer, which is an organic binder, are used when applying technology $\mathrm{C}$ and subsequent carbon emissions amount is $1,100 \mathrm{tCO}_{2} / \mathrm{km}$. Carbon emissions coefficient in the binder applied in this case is $0.002407 \mathrm{tCO}_{2} / \mathrm{kg}$ (Korea LCI database).

Work of construction and reused soil transportation are the same as technology $\mathrm{C}$ and the existing technology but the former reduces carbon emissions since there is no construction need for the anti-freezing layer, sub-base layer and pavement layer. Carbon emissions coefficient of each construction work (based on $1 \mathrm{~km}$ construction) is the same as shown in Table II. Carbon emissions reduced by replacing concrete slab and sub-base layer to soil pavement is 1,505 $\mathrm{tCO}_{2} / \mathrm{km}$ and total reduction in carbon emissions by applying technology $\mathrm{C}$ is $404.97 \mathrm{tCO}_{2} / \mathrm{km}$.

\section{CONCLUSION}

This study calculated reduction of carbon emissions when applying the three green highway technologies related to construction materials and road construction i.e. (technology A) manufacture and construction of carbon-absorbing road facilities utilizing activated industrial by-products, (technology B) low carbon non-cement soil pavement utilizing industrial by-products and inorganic binder and (technology C) low carbon soil pavement utilizing polymer concrete.

Analysis pointed that technology A can reduce carbon emissions by $27.44 \mathrm{tCO}_{2} / \mathrm{km}$ but this figure is based on when the technology is applied to curb only. Reduction of carbon emissions, therefore, is anticipated to be greater if the technology is applied further to other road facilities like retaining walls, medium barriers, etc. In technology B, change in carbon emissions is calculated when the amount of materials and the materials themselves used for the existing soil pavement technology changes. In technology $\mathrm{C}$, reduction in carbon emissions is driven by the change in construction work when the existing cement concrete slab, sub-base layer and anti-freezing layer are replaced to soil pavement. Unfortunately, the impact of technology B and C cannot be directly compared and analysis results of reduction may change depending on how the existing technologies compared with the three technologies are defined.

The case in which a certain road section is designed by applying the existing technologies and that in which a section is designed by applying a green technology (individually or in combination) should be compared, too. Also, cost variance other than reduction in carbon emissions should be taken into account since investment for technological development may be discouraged if cost is too high.

This study provides information on new green technologies applicable to designing and building new roads, and shares methodologies researchers and policy-makers may consider when making decisions.

\section{REFERENCES}

[1] SEI, Fact Sheet: Environmental Accounting for People and Places, Stockholm Environment Institute, 2008.

[2] HDM Global, HDM-4 Version 2. (2014). [Online]. Available: http://www.hdmglobal.com/hdm4v2information.asp

[3] US FHWA, INVEST (Infrastructure Voluntary Evaluation Sustainability Tool). (2014). [Online]. Available: https://www.sustainablehighways.org/

[4] Calculator for Harmonised Assessment and Normalisation of Greenhouse-gas Emissions for Roads. (September 2014). [Online]. Available: http://www.irfghg.org/index.php

[5] Greenhouse Gas Accounting Tool for Construction Guideline, Department of Planning Transport and Infrastructure, Government of South Australia, 2012.

[6] A. Dilger, C. Riley, S. Young, J. Bengtsson, and B. Kneppers, Greenhouse Gas Assessment Workbook for Road Projects, Transport Authorities Greenhouse Group Australia and New Zealand (TAGG), 2011.

[7] ROADEO (Road Emissions Optimization), A Toolkit for Greenhouse Gas Emissions Mitigation in Road Construction and Rehabilitation, September 2014

[8] CDIAC, Highest Emitting Nations Based on the Latest (2010) Estimates, Jul. 2014.

[9] Greenhouse Gas Inventory \& Research Center of Korea, Korea's Third National Communication under the United Nations Framework Convention on Climate Change, 2011.

[10] Korea Institute of Civil Engineering and Building Technology. (Jul. 2014). Research Project on carbon neutral road technologies development. [Online]. Available: http://greenhighway.kict.re.kr

[11] Korea Environmental Industry and Technology Institute. (Aug. 2014) LCI Database carbon emissions coefficient. [Online]. Available: http://www.edp.or.kr/lci/co2.asp

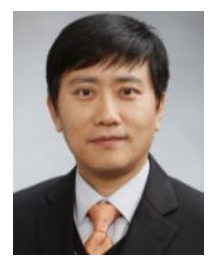

Jongdaeg Baek received his bachelor of engineering degree from the University of Seoul in 1999. He continued his study as a graduate student in the Department of Transportation Engineering at the same university and received his master of engineering degree in 2001. After two years of work experience as a researcher at the Korea Institute of Civil Engineering and Building Technology (KICT), he went to Raleigh, North Carolina to pursue a Ph.D. in degree civil engineering at North Carolina State University in 2003 and received his Ph.D. degree in 2007. After four years of his work as a post doc at the Highway Safety Research Center at the University of North Carolina, he came back to Korea and has been working at Highway \& Transportation Research Division in KICT as a senior researcher. His areas of experience include road geometry improvement, road safety countermeasure evaluation, and recently sustainable road strategies.

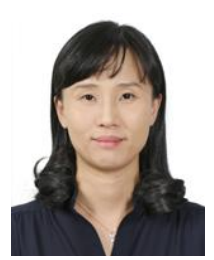

Hyejung $\mathrm{Hu}$ is a senior researcher at Korea Institute of Civil Engineering and Building Technology (KICT). She received her bachelor of engineering degree in urban engineering from Hongik University in 1999. She decided to focus on studying transportation engineering and studied for her master degree at the University of Seoul which is one of the great schools in transportation engineering in Korea. After receiving her master degree in 2001, she worked at the Government of Seoul City for two years. Her duty was improving the Seoul traffic signal operation systems. She went to North Carolina State University in 2003 and earned her Ph.D. degree in 2009. After two years of her post doc period at the Institute for Transportation Research and Education in NCSU, she came back to Korea and began to work at KICT. She is currently involved in various researches on sustainability of transportation. 


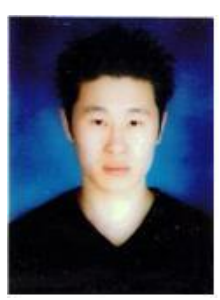

Guenhee Lee is an associate researcher at Korea Institute of Civil Engineering and Building Technology (KICT). He received his bachelor of engineering degree in urban engineering from Daejin University in 2007. He received his master of engineering degree in urban engineering from Hanyang University in 2009. He decided to focus on studying transportation engineering after receiving his master degree and is taking a Ph.D. degree course at the same university. He is currently involved in various researches on

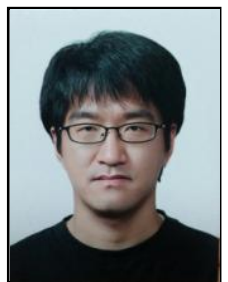

Kunho Kim received his bachelor of engineering degree at Kwangwoon University in 2006. Since 2010, he has been working at Institute for Sustainability Strategy in YESSorg Co., Ltd. His areas of experience include estimation of carbon emissions, life cycle assessment, and recently sustainable road strategies. 